\title{
O uso da matriz óssea desmineralizada na reparação de lesões osteocondrais. Estudo experimental em coelhos.
}

\author{
The use of demineralized bone matrix in the repair of osteochondral lesions.
}

Experimental study in rabbits.

Aldo José Fernando da Costa ${ }^{1}$, Cláudia Regina Gomes Cardin Mendes de Olneira ${ }^{2}$, Natalino Leopizzi ${ }^{3}$, Marco Martins Amatuzzl ${ }^{4}$

\section{RESUMO}

Este estudo teve como finalidade a avaliação do uso de matriz óssea desmineralizada na reparação de lesões osteocondrais. A cartilagem articular tem pequena capacidade regenerativa devido a suas características histológicas e à ausência de vasos sanguíneos. Implantes teciduais e cultura de células condrogênicas foram utilizadas para o tratamento de lesões osteocondrais, porém trazem dificuldades técnicas na fixação e suporte mecânico da região subcondral. A matriz óssea desmineralizada pode facilitar tecnicamente a fixação destes implantes em razão de ser um material firme, porém com características elásticas. Além de ter capacidade osteogênica e produzir osso subcondral, assim funcionando como suporte mecânico, também tem fatores indutores de condrogênese. Lesões osteocondrais foram produzidas em joelhos de 15 coelhos. Os joelhos esquerdos foram tratados com matriz óssea desmineralizada, e os direitos usados como controle comparativo. Realizaram-se avaliações macroscópicas e histológicas nas semanas 02, 04 e 06. Nas lesões tratadas com matriz óssea desmineralizada foi obtido 100\% de viabilidade do enxerto e formação de tecido normal de reparação, o qual preencheu a lesão completamente com matriz óssea desmineralizada. A análise histológica demonstrou neoformação óssea e integração do enxerto com o tecido ósseo da região subcondral, e na região superficial da lesão ocorrera a indução de formação de tecido condrogênico. A conclusão deste estudo é que a matriz óssea desmineralizada é útil na reparação de lesões osteocondrais devido a sua capacidade de indução óssea e indução de formação de tecido condrogênico. Pode ser usada no tratamento de lesões osteocondrais como componente de um enxerto composto com tecido condrogênico ou cultura de células condrogênicas. Pode também diminuir as dificuldades técnicas de fixação e suporte estes implantes.

\section{INTRODUÇÃO}

A cartilagem hialina reveste a superfície das articulações e tem, como característica principal, a capacidade de suportar intensas e repetidas forças de compressão e de tração.

\section{SUMMARY}

This study evaluated the use of the demineralized bone matrix in the repair of osteochondral lesions. The articular cartilage has little regeneration capacity because of its histological features and the absence of blood vessels. Implants of tissues and culture of chondrogenic cells have been used for the treatment of osteochondral lesions, but show technical difficulties of fixation and mechanical support of the subchondral region. The demineralized bone matrix can technically facilitate the fixation of these implants because it is a firm material with elastic features. Besides having osteogenic capacity and producing subchondral bone tissue and then working as mechanical support, it also has inductor factors of chondrogenesis. Osteochondral lesions were produced in the knees of 15 rabbits and the left knees were treated with the demineralized bone matrix, and the right knees were used like control of the study. Macroscopic and histological evaluations were made with 02, 04 and 06 weeks. In the lesions treated with the demineralized bone matrix it was obtained $100 \%$ of viability of the graft and the formation of a plain regular repair tissue which filled the lesion completely with $D B M$. The histological analysis revealed bone neoformation and integration of the graft with the bone tissue in the subchondral region, and in superficial region of the lesion occurred the induction of the formation of chondrogenic tissue. The conclusion of this study is that the demineralized bone matrix is useful in the repair of osteochondral lesions because of its capacity of bone induction, integration to the subchondral bone tissue and induction of the formation of chondrogenic tissue. It can be used as a component of a composite graft with chondrogenic tissue or culture of chondrogenic cells for the treatment of osteochondral lesions, and can decrease the technical difficulties of fixation and support of these implants.

\section{INTRODUCTION}

The hyaline cartilage covers the joints surface and has as main characteristic the capacity to support intensive and repetitive compression and tension load.
1 - Mestre em Ortopedia e Traumatologia pela Faculdade de Medicina da Universidade de São Paulo (FMUSP).

2 - Médica chefe da Seção de Anatomia Patológica do Instituto de Ortopedia e Traumatologia do Hospital das Clínicas da FMUSP (IOT-HCFMUSP).

3 - Médico veterinário do Laboratório de Investigações Médicas do Instituto de Ortopedia e Traumatologia do Hospital das Clínicas da FMUSP (IOT-HCFMUSP).

4 - Professor Titular do Departamento de Ortopedia e Traumatologia da FMUSP.

Trabalho recebido em 15/10/2000. Aprovado em 12/06/2001
1 - Master's Degree in Orthopedics and Traumatology by "Faculdade de Medicina da Universidade de São Paulo - FMUSP" (São Paulo Medical University).

2 - Doctor in charge of Pathologic Anatomy section of Institute of Orthopedics and Traumatology at "Hospital das Clínicas" of FMUSP (IOT-HCFMUSP).

3 - Veterinarian Doctor of "Laboratório de Investigações Médicas" of Institute of Orthopedics and Traumatology at "Hospital das Clínicas" of FMUSP (IOT-HCFMUSP). 4 - Titular head professor of Orthopedics and Traumatology Department at "Hospital das Clínicas" of FMUSP (IOT-HCFMUSP). 
É constituída por condrócitos e pela matriz extracelular

Os condrócitos têm a função de produzir e manter a matriz, enquanto a arquitetura e a composição desta têm influência direta sobre a função dos condrócitos ${ }^{(11)}$.

A cartilagem articular não possui vasos sanguíneos, vasos linfáticos e nervos. A nutrição dos condrócitos e o transporte dos seus metabólitos se faz por difusão através da matriz extracelular e dependem do líquido sinovial.

Esta cartilagem pode ser lesada por uma série de fatores mecânicos, químicos ou microbiológicos.

Pela sua característica histológica e por ser desprovida de aporte sanguíneo, as lesões da cartilagem articular possuem pouca ou nenhuma capacidade de regeneração. As lesões cartilaginosas geralmente evoluem para a doença articular degenerativa, caracterizada por dor, rigidez e perda da mobilidade articular. Esta doença está entre as causas mais comuns de dor e incapacidade entre as pessoas de meia-idade e os idosos.

O tratamento das lesões condrais e osteocondrais, continua sendo um desafio clínico e científico.

Existem vários métodos propostos para o tratamento, destacando-se o desbridamento da cartilagem lesada, perfurações da placa óssea subcondral, transplante de tecido condral, osteocondral, pericondral ou periosteal, e os de maior interesse na atualidade que utilizam o implante de cultura de células potencialmente condrogênicas, como condrócitos e células mesenquimais.

Estes últimos apresentam dificuldades técnicas de fixação do implante, muitas vezes ocasionando falhas por soltura do material implantado, ou pela falta de uma plataforma óssea subcondral para o seu suporte mecânico que pode levar a uma incongruência articular, quando submetida ao suporte de carga, nas lesões osteocondrais $^{(17,54,90)}$

Com o intuito de eliminar estas dificuldades técnicas, implantes biológicos como a matriz óssea desmineralizada, implantes sintéticos de fibras de carbono, compostos de colágeno e matrizes biodegradáveis, têm sido utilizados como componente de um enxerto composto, funcionando como condutor dos implantes.

A matriz óssea desmineralizada (MOD) por ser um material firme, com características elásticas, pode ser facilmente moldada para preencher lesões osteocondrais com diferentes tamanhos e formatos. Pode facilitar a fixação de implantes por técnicas de sutura ou pelo preenchimento de suas lacunas com as células potencialmente condrogênicas cultivadas. A MOD tem mostrado ter uma atividade osteoindutora importante. Além de poder promover neoformação óssea e integração com o tecido ósseo subcondral adjacente e assim funcionar como um suporte mecânico para estes implantes, também contém fatores indutores de condrogênese ${ }^{(49,78,85)}$.

O objetivo deste estudo é avaliar a utilização da

\section{Chondrocytes and extracellular matrix compose it.}

The chondrocytes are responsible for matrix synthesis and turnover, while the state of the matrix has a direct influence on chondrocyte function ${ }^{(11)}$.

The articular cartilage doesn't have blood and lymphatic vessels or nerves. The nutrition of the chondrocytes and the transport of their metabolites occur by diffusion through the extracellular matrix and depend on the synovial liquid.

This cartilage can be damaged by a variety of mechanical, chemical and microbiological factors.

Due to its histological features and lack of blood support the articular cartilage lesions own few or any regeneration capacity. The cartilage lesions usually develop to degenerative disease characterized by pain, stiffness and loss of articular mobility. This disease is among the most common causes of pain and incapacity among the elderly and adult people.

The chondral and osteochondral lesions treatment remains being a clinical and scientific challenge.

There are several methods for the treatment as the injured cartilage debridement; perforations through the subchondral bone; chondral, osteochondral, perichondral or periosteal tissue transplant and the treatment of major interest nowadays that use potentially chondrogenic cells culture implant like chondrocytes and mesenchymal cells.

The latest ones shows technical difficulties of implant fixation causing many times failure because of the implanted material loosing or due to the lack of subchondral bone platform for its mechanical support that can lead to an articular incongruence when under load support in the osteochondral lesions ${ }^{(17,54,90)}$

Intending to eliminate these technical difficulties, the biological implants as the Demineralized Bone Matrix (DBM), carbon fibers

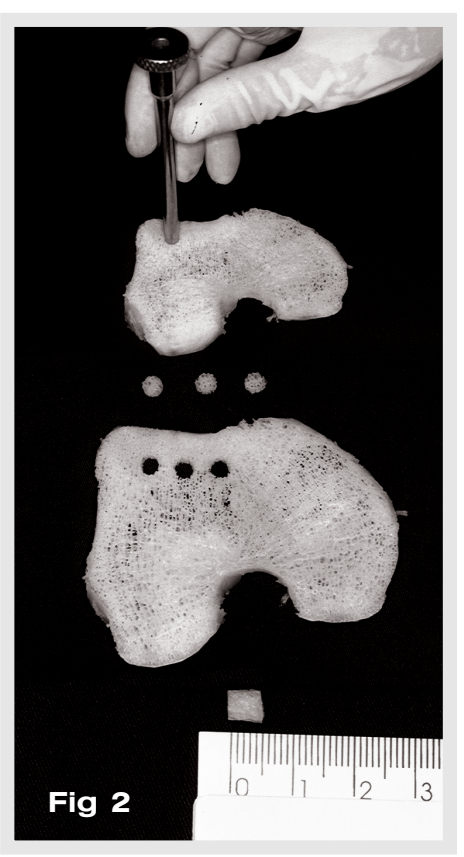
synthetic implants, collagens composite and biological reabsobable matrix have been used as a component of a composite graft working as implant conductor.

Once being a firm material with elastic features, the DBM can be easily shaped to fill osteochondral lesions with different forms and size. It can also facilitate the implant fixation by suture techniques or by the fulfillment of its lacunae with the potentially chondrogenics cultivated cells.

The DBM has showed an important osteoinductor factor. Besides being able to promote osteogenesis and integration with the adjacent subchondral bone tissue and this way working as a 
MOD no processo de reparação das lesões osteocondrais, analisando sua capacidade de neoformação óssea e integração com o tecido ósseo subcondral adjacente, e analisar sua capacidade de indução condrogênica.

\section{MATERIAL E MÉTODOS}

\section{MATRIZ ÓSSEA DESMINERALIZADA}

Foi utilizada MOD de osso esponjoso de cadáver humano, doador de múltiplos órgãos, livre de doenças sistêmicas e doenças infecciosas detectáveis. Após a retirada das estruturas adjacentes, a peça foi imersa em uma solução contendo clorofórmio e metanol, por um período de três horas, para retirada do conteúdo gorduroso.

Realizou-se o processo de liofilização com o processador Labiconco ${ }^{\circledR}$ (Labiconco Corporation, Kansas City, Missouri, USA), por um período de 15 dias, com uma temperatura que variou de $20^{\circ} \mathrm{C}$ negativos a $40^{\circ} \mathrm{C}$.

O material foi submetido a um processo de desmineralização em solução de ácido clorídrico a 0,6 Normal, por um período de seis horas, a uma temperatura de $4^{\circ} \mathrm{C}$.

Foram realizados cortes paralelos e retilíneos de $5,0 \mathrm{~mm}$ de espessura (Figura 01), e com o auxílio de uma trefina cirúrgica com diâmetro interno de $4,0 \mathrm{~mm}$, foram produzidos cilindros de MOD com 4,0mm de diâmetro por $5,0 \mathrm{~mm}$ de altura (Figura 02).

Estes cilindros foram esterilizados em óxido de etileno, para então serem utilizados como enxerto de MOD nas lesões osteocondrais produzidas no ato cirúrgico.

\section{ANIMAIS DE EXPERIMENTAÇÃO}

Foram utilizados 15 coelhos adultos, da raça New Zealand, pesando entre 2,0 e $3,5 \mathrm{Kg}$.

Os animais foram alojados em recipientes individuais, onde puderam deambular livremente.

\section{TÉCNICA CIRÚRGICA}

Foram produzidas lesões osteocondrais $(07,17,18,19,89)$. Os joelhos esquerdos foram tratados com o enxerto de MOD, e

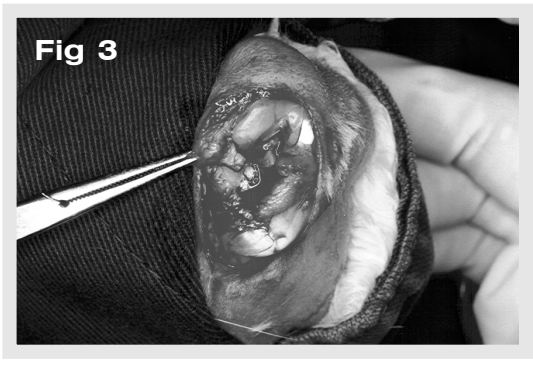

mechanical support for these implants, it also has chondrogenic inductive factors ${ }^{(49,78,85)}$.

The purpose of this study is to evaluate the use of DBM in the process of osteochondral lesion repair, analyzing its capacity of osteogenesis and integration with the adjacent subchondral bone tissue and also analyze its chondrogenic induction capacity.
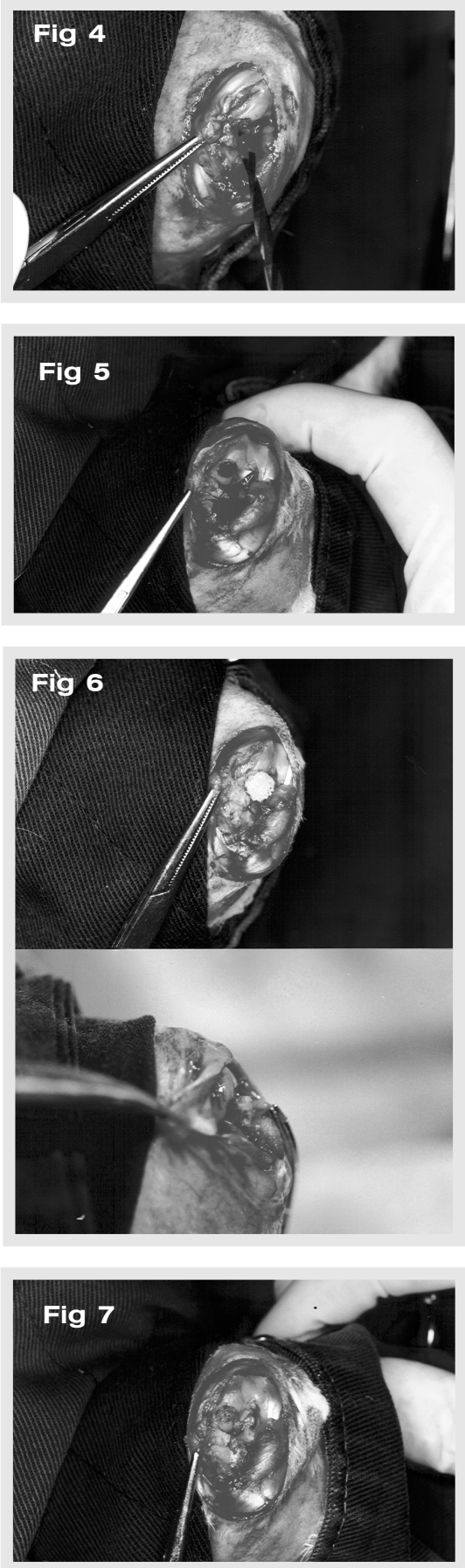

\section{MATERIALS AND METHODS}

\section{DEMINERALIZED BONE MATRIX}

The used DBM was from a human cancellous bone multiple organs donor, without systemic diseases and detectable infectious diseases. The surrounding structures were withdrawn and the piece was immersed in a methanol/chloroform solution for a 3-hour period, in order to remove the fat contents.

Lyophilization process was made with the Labiconco ${ }^{\circledR}$ processing machine (Labiconco Corporation, Kansas City, Missouri, USA), for a period of 15 days under a temperature ranging from $-20^{\circ} \mathrm{C}$ to $40^{\circ} \mathrm{C}$. The material was submitted to a process of demineralization in a chloridric acid solution $0,6 \mathrm{~N}$ for a period of 6 hours under a temperature of $4^{\circ} \mathrm{C}$.

Parallel and rectilinear cuts $5 \mathrm{~mm}$ thick were made (Fig. 01) and with help of a surgical trephine, with $4.0 \mathrm{~mm}$ internal diameter, were produced cylinders of DBM with $4.00 \mathrm{~mm}$ of diameter by $5.0 \mathrm{~mm}$ height (Fig. 02).

This cylinders where sterilized in ethylene oxide to be used as DBM graft in osteochondral lesions produced during surgery.

\section{ANIMALS}

Fifteen adult New Zealand white rabbits weighing 2.0 to 3.5 Kilograms were used.

The animals where placed in individual containers where they were able to walk freely.

\section{SURGICAL MODEL}

Osteochondral lesions were produced $(07,17,18,19,89)$. The left knees were treated with DBM graft and the right knees served as study control.

The animals were submitted to an 
os joelhos direitos serviram de controle do estudo.

Os animais foram submetidos à anestesia geral inalatória com halotano na concentração de 5\%, complementada com injeção intramuscular de ketamina, na dose de $80 \mathrm{mg} / \mathrm{Kg}$ de peso.

Realizou-se incisão parapatelar medial, a patela foi luxada lateralmente e o joelho fletido para a exposição do côndilo femoral medial (Figura 03).

Na área central da região posterior do côndilo femoral medial, realizaram-se perfurações manuais com brocas autoperfurantes de 1, 2,5 e 3,5mm seqüencialmente (Figura 04), criando-se uma lesão osteocondral de formato cilíndrico com 3,5mm de diâmetro e $5 \mathrm{~mm}$ de profundidade. (Figura 05).

No joelho esquerdo foi introduzido o enxerto de MOD que fixou-se por um mecanismo de pressão (Figuras 06 e 07).

No joelho direito apenas foi produzida a lesão osteocondral e serviu de controle do estudo.

No pós-operatório cada animal recebeu uma dose de 50.000 $\mathrm{UI} / \mathrm{Kg}$ de penicilina benzatina por via intramuscular e os animais foram mantidos em recipientes separados, livres para a deambulação.

\section{GRUPOS DE EXPERIMENTAÇÃO}

Os animais foram divididos aleatoriamente em 03 grupos de 05 animais, denominados Grupo A, B e C. Cada grupo foi submetido à eutanásia respectivamente com 02, 04 e 06 semanas após o ato cirúrgico.

\section{CRITÉRIOS DE AVALIAÇÃO}

\subsection{Critérios Macroscópicos:}

Foram analisados o aspecto da ferida cirúrgica; a mobilidade passiva do joelho; o aspecto da cartilagem de contato na região tibial; o aspecto do tecido sinovial; a viabilidade do enxerto da MOD nos joelhos tratados, definido como a presença de um tecido de reparação firme, preenchendo toda a lesão e contínuo com o tecido ósseo subcondral que o circunda ${ }^{(01,07,18)}$; e as características do tecido de reparação.

\subsection{Critérios Histológicos:}

Foram realizados cortes histológicos, que foram corados pelo método de hematoxilina-eosina.

A análise histológica realizou-se por método qualitativo, onde foram avaliadas as seguintes variáveis, relacionadas à natureza do tecido de reparação:

1) Região subcondral da lesão osteocondral: presença de processo inflamatório crônico inespecífico; as características do tecido de reparação: neoformação óssea ou com tecido fibroso; e a integração óssea do enxerto da MOD ao tecido ósseo subcondral, utilizando-se o sistema de graduação histológica descrito por Billings et al. (1990).

2) Região superficial da lesão osteocondral: características do processo de reparação: tecido fibroso, tecido mesenquimal indiferenciado, cartilagem hialina imatura ou cartilagem hialina madura, conforme os critérios descritos por Kim et al. (1991). inhalant general anesthesia with halotano in 5\% concentration, complemented with ketamine intramuscular injection $(80 \mathrm{mg} / \mathrm{kg}$ body weight).

A medial parapatelar incision was made, the patella was dislocated laterally and the knee was inflected to the exposition of the medial femoral condyle (Fig. 03).

In the central area of the posterior region of the medial femoral condyle, hand perforations were made with selfperforating drills of 1, 2.5 and 3.5mm sequentially (Fig.04), creating an osteochondral lesion of cylindrical shape with $3.5 \mathrm{~mm}$ of diameter and 5.0mmdeep.(Fig. 05).

In the left knee was introduced the DBM graft which fixation was by a pressure mechanism (Fig. 06 and 07).

In the right knee only the osteochondral lesion was produced and served as control of study.

Postoperatively each animal received 50,000 UI/Kg of Benzatine penicillin intramuscle and the animals were housed in individual cages and allowed to move freely.

\section{EXPERIMENTAL GROUPS}

The animals were divided randomly in three groups of five animals named Group A, B and C.

Each group was submitted to euthanasia respectively with 02 , 04 and 06 weeks after the surgery.

\section{EVALUATION CRITERIA}

\subsection{Macroscopic Criteria}

The surgical wound aspect was analyzed; the passive mobility of the knee; the aspect of contact cartilage in the tibia region; the aspect of the synovial tissue; the viability of the DBM graft in the treated knees, defined as the presence of a steady repair tissue, fulfilling all the lesion and continuous with the subchondral bone tissue that surrounds it(01,07,18), and the features of the repair tissue.

\subsection{Histological Criteria}

Histological sections were done and were stained by the hematoxilin-eosin method.

The histological analysis was done by qualitative method.

The following features were evaluated:

1) Subchondral area of the osteochondral lesion: presence of not specific chronic inflammatory process; the characteristics of the repair tissue, osteogenesis or fibrous tissue; and DBM graft integration to the subchondral bone tissue using the system of histological graduation described by Billings et al. (1990).

2) Superficial area of the osteochondral lesion: characteristics of the process of repair tissue: fibrous tissue, undifferentiated mesenchymal tissue, immature hyaline cartilage or mature hyaline cartilage, according to the criteria described by Kim et al. (1991). 


\subsection{Análise Estatística:}

Para a análise estatística foram utilizados o teste exato de Fisher e o teste da Razão de Verossimilhança. Os resultados considerados significantes são os que possuem relações de dependência ao tratamento com nível de $5 \%$ de significância, e são destacados por um asterisco $\left(^{*}\right)$.

\section{RESULTADOS}

\section{ASPECTOS MACROSCÓPICOS}

Não foi observada infecção superficial ou profunda. A mobilidade articular do joelho permaneceu com amplitude inalterada.

Não foram encontradas alterações macroscópicas na cartilagem articular tibial medial de contato. O tecido sinovial também não apresentou alterações de espessura e coloração.

Obteve-se um índice de 100\% de viabilidade do enxerto.

Quanto as características macroscópicas do tecido de reparação, observou-se um predomínio da formação de um tecido de reparação com preenchimento total da lesão, com características planas e superfície regular nos grupos tratados (figura 08), enquanto nos grupos controle observou-se a produção de um tecido de reparação preenchendo parcialmente a lesão, de uma forma retraída e irregular (figura 09).

\section{ASPECTOS HISTOLÓGICOS}

A figura 11 demonstra um exemplo do aspecto histológico da região subcondral da lesão tratada com a MOD, evidenciando a ocorrência de neoformação óssea, e a figura 12 demonstra um exemplo do aspecto histológico da região subcondral da lesão sem tratamento, do grupo controle, evidenciando a ocorrência de tecido fibroso, como tecido de reparação.

Quanto à integração da MOD ao tecido ósseo subcondral, a distribuição das pontuações conforme a classificação estabelecida, pode ser analisada na Tabela 02.
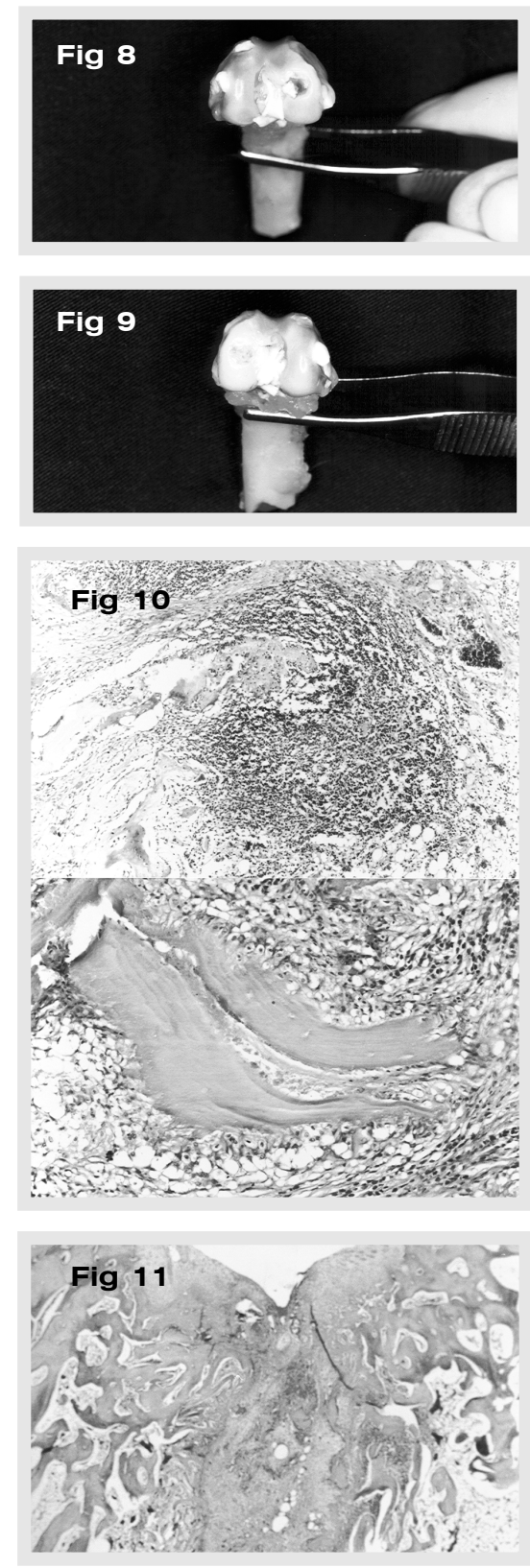

Tabela 01 - Ocorrência absoluta e relativa (\%) da formação do tecido de reparação com tecido fibroso ou com neoformação óssea na região subcondral da lesão

Table 01 - Absolute And Relative (\%) Occurrence Of The Repair Tissue Formation With Fibrous Tissue Or Osteogenesis In The Subchondral Area Of The Lesion

\begin{tabular}{|c|c|c|c|c|c|c|}
\hline \multirow{2}{*}{$\begin{array}{l}\text { TIPO DE } \\
\text { TECIDO } \\
\end{array}$} & \multicolumn{2}{|c|}{ GRUPO A } & \multicolumn{2}{|c|}{ GRUPO B } & \multicolumn{2}{|c|}{ GRUPO C } \\
\hline & Controle & Tratado & Controle & Tratado & Controle & Tratado \\
\hline $\bar{F}$ & $4(80 \%)$ & 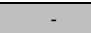 & $4(80 \%)$ & - & $3(60 \%)$ & - \\
\hline NO & $1(20 \%)$ & $5(100 \%)$ & $1(20 \%)$ & $5(100 \%)$ & $2(40 \%)$ & $5(100 \%)$ \\
\hline \multirow[t]{2}{*}{ TOTAIS } & $5(100 \%)$ & $5(100 \%)$ & $5(100 \%)$ & $5(100 \%)$ & $5(100 \%)$ & $5(100 \%)$ \\
\hline & \multicolumn{2}{|c|}{$p=0,05^{*}$} & \multicolumn{2}{|c|}{$p=0,05^{*}$} & \multicolumn{2}{|c|}{$p=0,17$} \\
\hline
\end{tabular}

$\boldsymbol{F}=$ Tecido de reparação com tecido fibroso - Repair Tissue with Fibrous tissue

NO = Tecido de reparação com características de neoformação óssea- Repair Tissue with Osteogenesis $\mathbf{P}=$ Teste de Fisher - Fisher test
Figure 11 shows an example of the histological aspect of the subchondral area of the DBM graft treated lesion, making clear the osteogenesis occurrence, and figure 12 shows an example of the histological aspect of the subchondral area of the lesion without treatment (control group), making clear the fibrous tissue occurrence, as repair tissue.

Histological scoring results of the graft integration to the subchondral tissue can be analyzed in Table 02. 


\subsection{Região Subcondral da Lesão Osteocondral}

Em todas as lesões osteocondrais tratadas com MOD, grupos tratados, observou-se a ocorrência de um processo inflamatório crônico inespecífico, predominantemente mononuclear, com presença de macrófagos e células gigantes do tipo corpo estranho (Figura 10).

Nos grupos controle a ocorrência deste processo inflamatório inespecífico ocorreu apenas em alguns casos e com uma intensidade menor.

A ocorrência dos tipos de tecidos de reparação predominante na região subcondral da lesão, tecido fibroso ou com neoformação óssea, pode ser observada na Tabela 01

\subsection{Região Superficial da Lesão} Osteocondral

Na região superficial da lesão osteocondral, em nenhum dos casos, observou-se a formação de cartilagem hialina madura. A distribuição dos tipos de tecidos de reparação predominante nesta região pode ser avaliada na Tabela 03.

\section{DISCUSSÃO}

\section{DO TRATAMENTO DAS LESÕES CAR- TILAGINOSAS}

Algumas lesões cartilaginosas não são progressivas, e a articulação pode retornar ao seu estado assintomático após uma lesão cartilaginosa ${ }^{(13,41)}$.

O desbridamento da cartilagem articular lesada pode aliviar os sintomas, por diminuir a instabilidade mecânica causada pelos fragmentos de cartilagem soltos, e por diminuir o processo inflamatório causado pelos debris intra-articulares ${ }^{(05,10)}$. Porém, não há evidências de que o desbridamento estimula a regeneração das lesões cartilaginosas ${ }^{(38)}$

Múltiplas perfuração na placa óssea subcondral podem induzir a condrogênese nas lesões cartilaginosas ${ }^{(22,33,34,43)}$, porém com o tempo, ocorre deterioração do tecido de regeneração ${ }^{(10,43)}$.

Enxertos osteocondrais alogênicos ou autólogos têm sido utilizados para o trata-
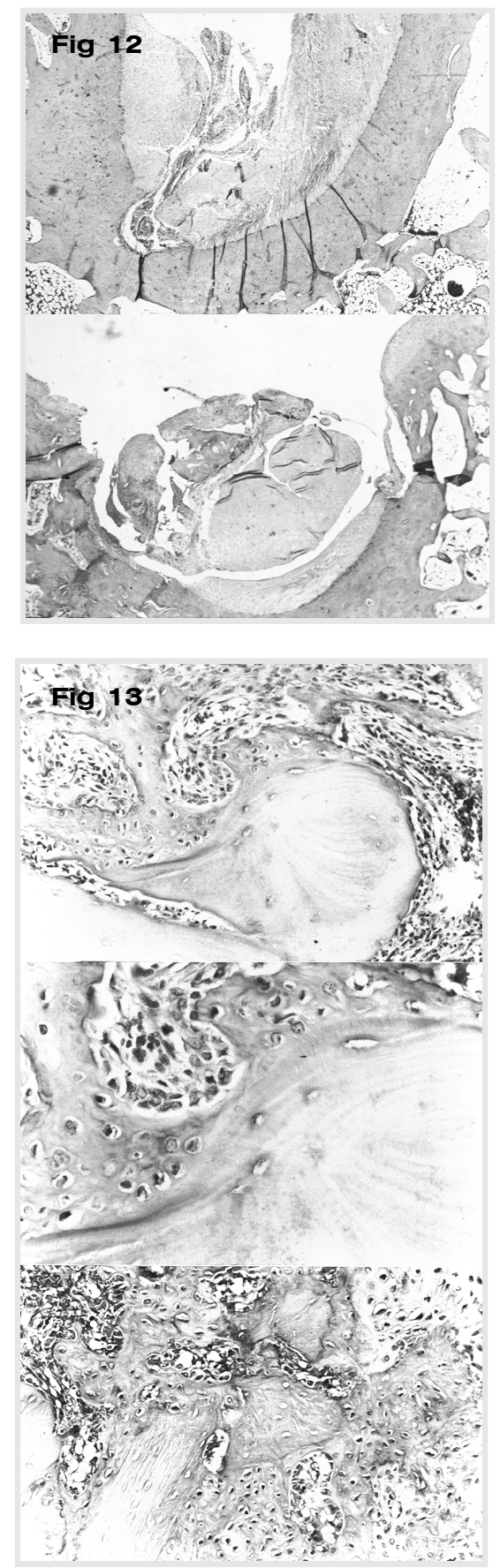

2. HISTOLOGICAL ASPECTS

2.1 Subchondral Area of Osteochondral Lesion

Not specific chronic

inflammatory process occurred

in all osteochondral lesions

treated with DBM graft. It was essentially mononuclear cells,

with the presence of

macrophages and foreign

body giant cells. (Fig. 10).

This not specific chronic inflammatory process occurred only in a few cases and with small intensity in the control groups.

The occurrence of the predominant repair tissue types in the subchondral area

of the lesion, fibrous tissue or osteogenesis, can be observed in Table 01

\subsection{Superficial Area of the} Osteochondral Lesion

Mature hyaline cartilage formation wasn't observed in any case.

The distribution of the predominant repair tissue types on the superficial area of the lesion can be observed in Table 03.

\section{DISCUSSION}

\section{TREATMENT OF THE CARTILAGE LESIONS}

Some cartilage lesions aren't progressive, and the joint can return to the asymptomatic status after it ${ }^{(13,41)}$

Debridement of the articular cartilage lesion can relief the symptoms by reducing the mechanical instability caused by free cartilage fragments and by reducing the inflammatory process caused by intraarticular debris ${ }^{(05,10)}$. However there is no evidence that the debridement stimulates the cartilage lesion regeneration ${ }^{(38)}$.

Multiple perforation trough the subchondral bone can induce the chondrogenesis $(22,33,34,43)$, however as time passed, deterioration of the regeneration tissue occurred ${ }^{(10,43)}$

Osteoarticular allografts have been utilized for the treatment of the cartilage lesion with good results $(03,06,23,74,95)$. To obtain these results, 
mento das lesões cartilaginosas com bons resultados $(03,06,23,74,95)$. Para obter-se estes resultados, existe a necessidade do enxerto corresponder anatomica-mente à região receptora, para que ocorra um perfeito acoplamento da altura e do contorno da superfície articular, e uma fixação rígida do enxerto. Porém, a reabsorção do tecido ósseo pode ocorrer e levar a um colapso da cartilagem com maus resultados.

O uso de tecido pericondral ${ }^{(17,18,30)}$, periosteal e osteoperiosteal ${ }^{(46,55,56,57,64)}$ também tem sido relatado com altos índices de sucesso.

De grande interesse na atualidade são os implante de cultura de células potencialmente condrogênicas, como cultura de condrócitos ${ }^{(09,12,25,35,54,90)}$ e cultura de células mesenquimais ${ }^{(52,89)}$

Os estudos que utilizam como método de tratamento o implante de tecidos ou cultura de células potencialmente condrogênicos relatam dificuldades técnicas de fixação do implante, que muitas vezes ocasionam falhas do procedimento por soltura do material implantado $^{(01,02,17,18,46)}$

Da mesma maneira, a falta de uma plataforma óssea subcondral, funcionando como um suporte mecânico para estes implantes, pode levar a uma incongruência articular, quando esta articulação for submetida a um suporte de carga, e também ocasionar falha no procedimento ${ }^{54,90}$

Na tentativa de solucionar estes problemas técnicos, alguns materiais têm sido utilizados como um componente de um enxerto composto, funcionando como condutor destes implantes.

\section{DA MATRIZ ÓSSEA DESMINERA- LIZADA}

Senn ${ }^{(71)}$, em 1889, foi quem primeiro relatou o uso da MOD. Porém. apenas na década de 1960, a capacidade osteo-indutora da MOD foi comprovada e detalhada $(32,73,78,85,88,96)$

Atualmente sabe-se que a MOD contém diversas moléculas bioativas, que agem como fatores de crescimento, entre elas as

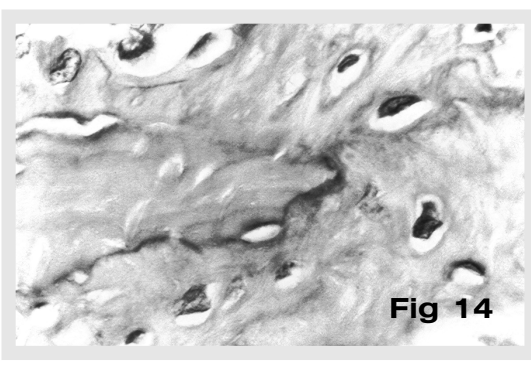
difficulties of graft fixation, that cause several times procedure failure by graft loosing $(01,02,17,18,46)$

In the same way, due to the lack of subchondral bone platform working as mechanical support for these grafts can lead to articular incongruence when under load support and can also cause procedure failure (54,90).

Intending to eliminate these technical difficulties some materials have been used like a component of a composite graft working as implant conductor.

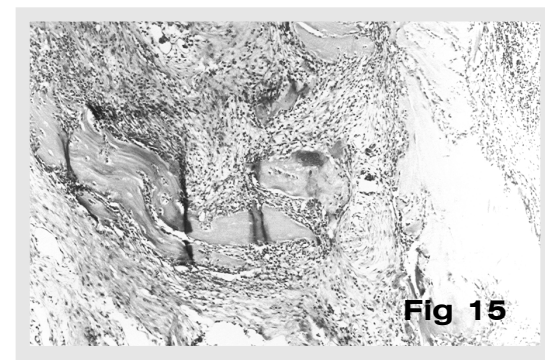

\section{DEMINERALIZED BONE MATRIX}

Senn ${ }^{(71)}$ made the first study about the DBM use in 1889. However, only in the 1960's the osteogenesis properties of the DBM were proved and detailed $(32,73,78,85,88,96)$.

Nowadays it is known that the DBM has several molecules that act like growth factors, among them, the bone morphogenetic proteins (BMPs) which can be isolated and genetically cloned $(14,82,83,91,92,94)$.

The bone matrix demineralization process

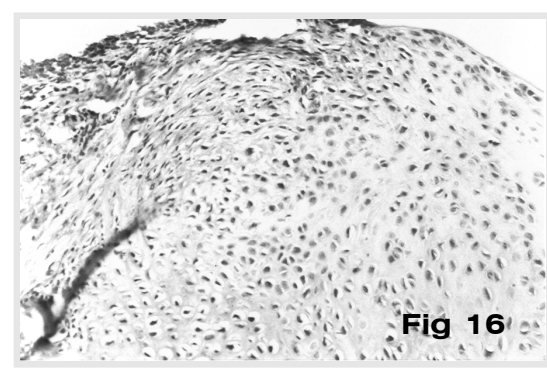
promotes a BMP exposure allowing the occurrence of cellular interactions of these BMPs with undifferentiated mesenchymal cells $S^{(20,81,86)}$.

Thus the DBM has a higher osteogenesis capacity than the mineralized bone matrix $(24,60,93)$ 
proteínas morfogenéticas ósseas (PMOs), que podem ser isola-

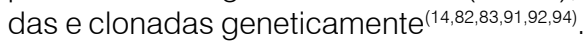

O processo de desmineralização da matriz óssea promove uma exposição das PMOs, favorecendo a ocorrência de interações celulares destas proteínas com as células mesenquimais indiferenciadas $^{(20,81,86)}$.

Desta forma, a MOD possui uma capacidade osteoindutora maior que a matriz óssea não desmineralizada(24,60,93).

Além da sua capacidade osteoindutora, a MOD também contém substâncias bioativas com capacidade condrogênica.

Vários estudos demonstram a capacidade de transformação de mioblastos em condrócitos na presença da MOD, sugerindo que as substâncias bioativas da MOD podem alterar o caminho da diferenciação de células progenitoras ${ }^{(31,48,49,50,53,67,84,87)}$.

Estas substâncias bioativas foram isoladas ${ }^{(69,72)}$, sendo comprovada a sua capacidade condrogênica.

Atualmente, PMOs clonadas geneticamente têm mostrado estimular a produção de ácido hialurônico e promover a condrogênese ${ }^{(40,70)}$.

\section{DA METODOLOGIA}

Foi utilizada MOD heteróloga de humano para o tratamento de lesões osteocondrais em coelhos.

Apesar dos estudos iniciais ${ }^{(66,68,78,85)}$ demonstrarem que não é possível obter neoformação óssea induzida por MOD heteróloga, com o aperfeiçoamento da técnica de preparação e purificação da MOD, foram observadas osteoindução com o uso de MOD heteróloga suína em coelhos ${ }^{(76)}$ e com o uso de MOD heteróloga humana em ratos ${ }^{(39)}$.

Apesar da MOD processada ser avascular e não conter células vivas, baixas quantidades de lipídios, adipócitos ou componentes proteícos não removidos adequadamente no seu processo de preparação, podem ser a causa do insucesso referidos nos trabalhos iniciais ${ }^{(08)}$.

Lipídios e lipoproteínas foram detectados após o processo de desmineralização e sua retirada demonstrou diminuir a resposta imune e aumentar a capacidade de osteoindução ${ }^{(39,85)}$.

A MOD quando preparada com uma solução de clorofórmio e metanol, tem os lipídios removidos e promove uma melhora na capacidade de osteoindução(04,15).

Apesar das controvérsias sobre a viabilidade do enxerto heterólogo, existem relatos da utilização da MOD heteróloga com bons resultados $(16,21,26,37,42,47,51,71,77)$.

O processo de liofilização é importante para preservar a matriz óssea e diminuir a possibilidade de contaminação.

O processo de desmineralização promove a destruição da alta antigenicidade das membranas celulares e das glicoproteínas $^{(26,27,29)}$ e a capacidade de indução pode ser preservada controlando-se a temperatura, o tempo de exposição e a concentração do ácido utilizado, sendo que o ácido clorídrico é o mais eficiente ${ }^{(80)}$.

O processo de esterilização foi realizado com óxido de etileno, mostrando-se eficaz e não interferindo na capacidade de osteoindução da MOD, principalmente quando esta é submetida
Besides its osteogenesis capacity the DBM also contains molecules with chondrogenic capacity.

Many studies show the embryonic muscle cells capacity of transformation in chondrocytes in the presence of DBM, suggesting that DBM molecules can alter the way of differentiation of progenitor

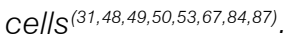

These molecules were isolated ${ }^{(69,72)}$ and their chondrogenic capacity has been proved.

Nowadays genetically cloned BMPs have shown to stimulate the production of hyaluronic acid and promote chondrogenesis ${ }^{(40,70)}$.

\section{METHODOLOGY}

Xenograft human DBM was used for the treatment of osteochondral lesions in rabbits.

Despite initial studies ${ }^{(66,68,78,85)}$ demonstrate that it is not possible to obtain osteogenesis induced by xenograft DBM with the improvement of the DBM preparation and purification techniques, it was observed osteogenesis with swine DBM xenograft in rabbits ${ }^{(76)}$ and human DBM xenograft in rats ${ }^{(39)}$.

Despite processed DBM being avascular and containing no living cells, residual low level lipids, adipocytic and protein components not properly removed during demineralization may be the cause of an unsuccessful the initial studies( ${ }^{(08)}$.

Lipids and lipoproteins were detected after demineralization and their extraction demonstrated to reduce the immune response and increase the osteoinductive response ${ }^{(39,85)}$.

When the DBM is prepared with chloroform/methano/ solution having removed lipids results a best osteogenesis capacity ${ }^{(04,15)}$.

In spite of controversies about the xenograft DBM viability, there are studies about the use of xenograft DBM with good

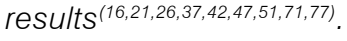

The process of Lyophilization is important to preserve the bone matrix and reduce the contamination possibility.

The demineralization process promotes the destruction of the high antigenic of the cell membranes and of the glicoproteins ${ }^{(26,27,29)}$ and the capacity of induction may be preserved by controlling the temperature, exposure time and used acid concentration seeing that the chloridric acid is the most efficient ${ }^{(80)}$.

The sterilization was made with ethylene oxide showing efficacy and not interfering osteoinduction, mainly when submitted previously to DBM lyophilization process and lipids components removal(28,36,44,97).

\section{MACROSCOPIC RESULTS}

The absence of infection and remaining articular mobility are due to the antiseptic and prophylactic methods used and to the free movement of the animals in the postoperative period.

These data contribute to the validation of the experimental method used and its reproducibility.

The absence of macroscopic alteration in the medial tibial articular cartilage in contact with the femoral condyle occurred due to the short time of experimental observation. Degeneration features would probably have been found with longer periods of observation mainly 
anteriormente ao processo de liofilização e retirada de componentes lipídicos ${ }^{(28,36,44,97)}$.

\section{DOS RESULTADOS MACROSCÓPICOS}

A ausência de infecção e a permanência da amplitude articular deve-se aos métodos anti-sépticos e profiláticos utilizados e à livre deambulação dos animais no pós operatório. Estes dados contribuem para a validação do método experimental empregado e sua reprodutibilidade.

A ausência de alterações macroscópicas da cartilagem articular tibial em contato com os côndilos femorais ocorreu devido ao tempo relativamente pequeno de observação experimental. Com períodos mais longos de observação, achados degenerativos desta cartilagem de contato provavelmente teriam sido encontrados, principalmente nos experimentos do grupo controle onde ocorreu preenchimento incompleto da lesão pelo tecido de reparação, nos quais se tem uma incongruência articular.

Obtivemos $100 \%$ de viabilidade do enxerto, conforme os critérios macroscópicos estabelecidos. Este fato deve-se ao mecanismo de fixação utilizado. O enxerto de MOD tem o mesmo formato da lesão produzida, porém com diâmetro 0,5 mm maior, fixando-se nesta por um mecanismo de pressão.

Outro fator que contribui para a fixação e manutenção do enxerto no local, é a característica da arquitetura espacial da MOD, que permite a penetração de células sangüíneas provenientes do tecido receptor. Estas células, em especial as plaquetas, em conjunto com a presença de fibrinogênio local, formam um agregado fibrino-plaquetário que promove a adesão do enxerto ao tecido receptor.

Observamos maior incidência do preenchimento total, plano e regular nos grupos tratados com a MOD. O preenchimento parcial da lesão nos grupos controle ocorreu porque o coágulo fibrino-plaquetário não foi suficiente para preencher totalmente a lesão.

\section{DOS RESULTADOS HISTOLÓGICOS}

\subsection{Região Subcondral da Lesão Osteocondral}

A presença do processo inflamatório inespecífico ocorreu em todos os casos tratados com a MOD. Este processo inflamatório ocorreu de forma mais intensa nos casos em que se obtiveram os maiores índices de integração da MOD ao tecido ósseo subcondral. Isto sugere um efeito positivo da ocorrência do processo inflamatório sobre o mecanismo osteoindutor da MOD. Os macrófagos derivados de monócitos parecem ter um papel importante no processo de reparação utilizando a MOD, pois a sua presença induz a neoformação vascular, que é vital para o processo de reparação e osteogênese ${ }^{(45,59,65)}$.

Quanto à ocorrência do tipo histológico do tecido de reparação encontrado na região subcondral da lesão osteocondral, observamos diferença estatística significante entre os grupos controle e os grupos tratados (Tabela 01).

Esta diferença ocorre pela presença dos fatores de crescimento, ou seja, das PMOs, na MOD. Estas proteínas rapidamente iniciam uma cascata de indução óssea, que inclui a quimiotaxia de células mesenquimais indiferenciadas, a proliferação das células in the control group partial fulfillment of the lesion and articular incongruence occurred.

It was obtained $100 \%$ ratios of DBM graft viability according to the established macroscopic criteria. This fact is due to the fixation mechanism used. The DBM graft has the same shape of the lesion, but with $0.5-\mathrm{mm}$ larger diameter, being fastened by pressure mechanism.

Other factor is the DBM spatial architecture characteristic that allowes the penetration of blood cells originated from the receptor tissue. These cells, especially the platelets and the local fibrinogen form an aggregated fibrinogen/platelets that promotes adherence between DBM and receptor tissue.

It was observed higher incidence of the total, plan and regular fulfillment in the groups treated with DBM. The partial fulfillment of the lesions in the contro/ groups occurred because the fibrinogen/ platelet aggregated was not enough to promote total fulfillment.

\section{HISTOLOGICAL RESULTS}

\subsection{Subchondral Area of the Osteochondral Lesion}

Not specific inflammatory process occurs in all cases treated with DBM graft. This inflammatory process occurred with more intensity in the cases in which the major ratio of integration between DBM graft to the subchondral bone tissue was obtained.

This suggests a positive effect of the inflammatory process occurrence over the DBM osteogenesis mechanism.

The monocyte-derived macrophage seem to play an important role in the repair process using DBM graft, because its presence induce the vascular neoformation which is essential to osteogenesis and repair process ${ }^{(45,59,65)}$.

It was observed significant statistical difference in the types of the repair tissue in the subchondral area of the lesion (Table 01). This difference occurs because of the presence of the BMPs in the DBM that began a bone induction cascade, which includes the undifferentiated mesenchymal cells chemotaxis, progenitor cells proliferation and bone and cartilaginous tissue differentiation ${ }^{(61,62,63)}$.

In the control groups occurs differentiation of the fibroblast in osteoblast, however with slow, ineffective and chaotic form.

DBM graft integration to the subchondral bone tissue occurred in a satisfactory way, with good integration ratio by the histological graduation system used (Table 02). We have noticed that this integration was improved progressively as time passed.

We also observed that the DBM graft was not reabsorbed and replaced for other tissue, as it occurs with the mineralized bone graft, but remained in the receptor bed and integrated with it ${ }^{(24,58,93)}$.

\subsection{Superficial Area of the Osteochondral Lesion}

Significant statistical difference was observed in the types of the repair tissue in the superficial area of the lesion (Table 03).

In the control groups the predominant repair tissue was the fibrous tissue. In the treated groups the predominant repair tissue was the undifferentiated mesenchymal tissue or immature hyaline cartilage.

These data suggest that the DBM graft has factors ${ }^{(40,49,70,72,75)}$ that induce mesenchymal cells differentiation in chondrocytes, that 
progenitoras e a diferenciação em tecido cartilaginoso e ós-

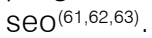

Nos grupos controle ocorrem estímulos para a diferenciação dos fibroblastos em osteoblastos, porém de uma forma caótica, lenta e ineficaz.

A integração da MOD ao tecido ósseo subcondral ocorreu de uma maneira satisfatória, com bons índices de integração pelo sistema de graduação histológica utilizado (Tabela 02). Notamos que esta integração foi melhorada progressivamente no decorrer do tempo.

Também observamos que o enxerto da MOD não foi reabsorvido e substituído por outro tecido, como ocorre com enxertos ósseos não desmineralizados, mas permaneceu no leito receptor e integrou-se ao mesmo $24,58,93)$.

\subsection{Região Superficial da Lesão Osteocondral}

Na região mais superficial da lesão osteocondral, observamos diferenças estatísticas siginificantes na ocorrência do tipo de tecido de reparação (Tabela 03).

Nos grupos controle, o tecido de reparação predominante foi o tecido fibroso. Nos grupos tratados, observamos predomínio de tecido mesenquimal indiferenciado ou cartilagem hialina imatura.

Estes dados sugerem que a MOD possui fatores que induzem a diferenciação de células mesenquimais em condrócitos, ou seja, fatores condrogênicos ${ }^{(40,49,70,72,75)}$.

Acreditamos que estes fatores presentes na MOD, que induzem condrogênese, podem atuar na preservação e desenvolvimento de tecidos ou cultura de células potencialmente condrogênicos apostas sobre a MOD num enxerto composto, para o tratamento de lesões osteocondrais.

Nos grupos tratados, não observamos relação entre o tempo e a ocorrência de tecido mesenquimal indiferenciado e cartilagem hialina imatura. Também não observamos nenhum caso de formação de cartilagem hialina madura.

Estes dados sugerem que a MOD não pode ser utilizada isoladamente para o tratamento de lesões osteocondrais.

\section{DAS CONCLUSÕES}

Com os resultados obtidos neste estudo, pudemos observar que a MOD é um tecido firme, com características elásticas, que pode ser moldado facilmente. Isto facilita o preenchimento de lesões osteocondrais de vários tamanhos e formatos, e facilita a aposição e fixação de tecidos e cultura de células potencialmente condrogênicos no tratamento das lesões osteocondrais.

A MOD possui uma importante capacidade osteoindutora, produzindo neoformação óssea, e integra-se ao tecido ósseo subcondral, promovendo assim, a formação de uma plataforma óssea subcondral. Esta plataforma óssea subcondral pode ser útil para assegurar a congruência articular, quando esta articulação for submetida ao suporte de carga. is, chondrogenic factors.

We believe that these chondrogenic factors in the DBM graft can act in the preservation and development of culture or tissues of potential chondrogenic cells, placed over the DBM producing a composite graft for the treatment of osteochondral lesion.

In the treated group we did not observe the relation between the time and the occurrence of undifferentiated mesenchymal tissue and immature hyaline cartilage. We also did not observe any case of mature hyaline cartilage formation.

These data suggest that the DBM can not be used to osteochondral lesion treatment alone.

\section{CONCLUSION}

With the results of this study, we could observe that the DBM is a firm tissue, with elastic characteristics, that can be easily shaped to fill osteochondral lesions of different shapes and sizes. This facilitates the placement and fixation of potential chondrogenic cells culture or tissue in the treatment of osteochondral lesion.

The DBM has an important osteogenesis capacity producing bone neoformation and integrate to the subchondral bone tissue promoting the formation of a subchondral bone platform. This subchondral bone platform can be useful to keep the articular congruence when this joint is submitted the load support.

The occurrence of undifferentiated mesenchymal tissue and immature hyaline cartilage formation suggest also the presence of chondrogenic inductor factors in DBM, which can help the permanence and development of potential chondrogenic cells' culture or tissue, if used in a composite graft for the treatment of osteochondral lesions.

The DBM, with these qualities described, is useful in the repair of osteochondral lesions and can be used as a component of the composite graft with potential chondrogenic cells' culture or tissue in the treatment of these lesions. 
A ocorrência da formação de tecido mesenquimal indiferenciado e da cartilagem hialina imatura, sugere também a presença de fatores indutores de condrogênese na MOD, que podem favorecer a permanência e o desenvolvimento de tecidos ou cultura de células potencialmente condrogênicos, se utilizados num enxerto composto, para o tratamento das lesões osteocondrais.

A MOD, com as qualidades descritas, é portanto, útil na reparação das lesões osteocondrais, podendo ser utilizada como um componente de um enxerto composto com tecido ou cultura de células potencialmente condrogênicos, no tratamento destas lesões.

\section{REFERÊNCIAS}

1 - AMIEL, D.; COUTTS, R.D: ABEL, M, STEWART, W : HARWWOD, F: AKESON, W.H Rib perichondrial grafts for the repair of full-thickness articular cartilage defects. A morphological and biochemical study in rabbits. J. Bone Joint Surg., v.67-A, p.91120, 1985.

2 - AMIEL, D.; COUTTS, R.D.; HARWOOD, F.L.; ISHIZUE, K.K.; KLEINER, J.B. The chondrogenesis of rib perichondrial grafts for repair of full thickness articular cartilage defects in a rabbit model: A one year postoperative assessment. Connect Tissue Res., v.18, p.27-39, 1988.

3 - AMIEL, D.; HARWOOD, F.L.; HOOVER, J.A.; MEYERS, M. A histological and biochemical assessment of the cartilage matrix obtained from in vitro storage of osteochondral allografts. Connect. Tissue Res., v.23, p.89-99, 1989.

4 - ASPENBERG, P.; THOREN, K. Lipid extraction enhances bank bone incorporation: an experiment in rabbits. Acta Orthop. Scand., v.61, p.546-8, 1990.

5 - BAUMGAERTNER, M.R.; CANNON, W.D., Jr; VITTORI, J.M.; SCHMIDT, E.S.; MAURER, R.C. Arthroscopic debridement of the arthritic knee. Clin. Orthop., n.253, p.197-202, 1990

6 - BEAVER, R.J.; MAHOMED, M.; BACKSTEIN, D.; DAVIS, A; ZUKOR, D.J. Fresh osteochondral allografts for post-traumatic defects in the knee. A survivorship analisys. J. Bone Joint Surg., v.74-B, p.105-10, 1992.

7 - BILLINGS, E., Jr.; VON SCHROEDER, H.P.; MAI, M.T.; ARATOW, M.; AMIEL, D.; WOO, S.L.-Y.; COUTTS, R.D. Cartilage resurfacing of the rabbit knee. The use of an allogeneic demineralized bone matrix-autogeneic perichondrium composite implant. Acta Orthop. Scand., v.61, p.201-06, 1990

8 - BLOCK, J.E.; POSER, J. Does xenogeneic demineralized bone matrix have clinical utility as a bone graft substitute? Medical Hypotheses, v.45, p.27-32, 1995.

9 - BRITTBERG, M.; NILSSON, A.; LINDAHL, A.; OHLSSON, C.; PETERSON, L. Rabbit articular cartilage defects treated with autologous cultured chondrocytes. Clin. Orthop., n.326, p.270-83, 1996.

10 - BUCKWALTER, J.A.; LOHMANDER, S. Operative treatment of osteoarthrosis. Current practice and future development. J. Bone Joint Surg., v.76-A, p.1405-18, 1994.

11 - BUCKWALTER, J.A.; MANKIN, H.J. Articular cartilage. Part I: tissue design and chondrocyte-matrix interactions. J. Bone Joint Surg., v.79-A, p.600-11, 1997.

12 - BUTNARIU-EPHRAT, M.; ROBINSON, D.; MENDES, D.G.; HALPERIN, N.; NEVO, Z. Resurfacing of goat articular cartilage by chondrocytes derived from bone marrow. Clin. Orthop., n.330, p.234-43, 1996

13 - CAMPBELL, C. J. The Healing of Cartilage Defects. Clin. Orthop., n.64, p.45-63, 1969.

14 - CELESTE, A..J.; IANNAZZI, J.A.; TAYLOR, R.C.; HEWICK, R.M.; ROSEN, V.; WANG, E.A.; WOZNEY, J.M. Identification of transforming growth factor $B$ family members present in bone-inductive protein purified from bovine bone. Proc. Natl. Acad. Sci. USA., v.87, p.9843-7, 1990.

15 - CHAPPARD, D.; FRESSONNET, C.; GENTRY, C.; BASLE, M.F.; REBEL, A. Fat in bone xenografts: importance of the purification procedures on cleanliness, wettability and biocompatibility. Biomaterials, v.14, p.507-12, 1993.

16 - CHESMEL, K.D.; BRANGER, J.; WERTHEIM, H.; SCARBOROUGH, N. Healing response to various forms of human demineralized bone matrix in athymic rat cranial defects. J. Oral Maxillofac. Surg., v.56, p.857-63, 1998

17 - CHU, C.R.; DOUNCHIS, J.S.; YOSHIOKA, M.; SAH, R.L.; COUTTS, R.D.; AMIEL, D Osteochondral repair using perichondrial cells. A 1-year study in rabbits. Clin. Orthop., n.304, p.220-9, 1997
18 - COUTTS, R.D.; WOO, S.L-Y.; AMIEL, D.; VON SCHROEDER, H.P.; KWAN, M.K. Rib perichondrial autografts in full-thickness articular cartilage defects in rabbits. Clin. Orthop., n.275, p.263-73, 1992

19 - DAHLBERG, L.; KREICBERGS, A. Demineralized allogeneic bone matrix for cartilage repair. J. Orthop. Res., v.9, p.11-19, 1991.

20 - DUBUC, F.L.; URIST, M.R. The accessibility of the bone induction principle in surface-decalcified bone implants. Clin. Orthop., n.55, p.217-23, 1967.

21 - EDWARDS, J.T.; DIEGMANN, M.H.; SCARBOROUGH, N.L. Osteoinduction of human demineralized bone: characterization in a rat model. Clin. Orthop., n.357, p.219-28, 1998.

22 - FICAT, R.P.; FICAT, C.; GEDEON, P.; TOUSSAINT, J.B. Spongialization: A new treatment for diseased patellae. Clin. Orthop., n.144, p.74-83, 1979.

23 - FLYNN, J.M.; SPRINGFIELD, D.S.; MANKIN, H.J. Osteoarticular allografts to treat distal femoral osteonecrosis. Clin. Orthop., n.303, p.38-43, 1994.

24 - GLOWACKI, J.; ALTOBELLI, D.; MULLIKEN, J.B. Fate of mineralized and demineralized osseous implants in cranial defects. Calcif. Tissue Int., v.33, p.71-6, 1981

25 - GREEN, W.T. Articular cartilage repair. Behavior of rabbit chondrocytes during tissue culture and subsequent allografting. Clin. Orthop., n.124, p.237-50, 1977.

26 - GUIZZARDI, S.; DI SILVESTRE, M.; SCANDROGLIO, R.; RUGGERI, A.; SAVINI, R Implants of heterologous demineralized bone matrix for induction of posterior spinal fusion in rats. Spine, v.17, p.701-7, 1992

27 - GUPTA, D.; TULI, S.M. Osteoinductivy of partially decalcified alloimplants in healing of large osteoperiosteal defects. Acta Orthop. Scand., v.53, p.857-65, 1982.

28 - HALLFEDT, K.K.J.; STÜTZLE, H.; PUHLMANN, M.; KESSLER, S.; SCHWEIBERER, L. Sterilization of partially demineralized bone matrix: the effects of different sterelization techniques on osteogenetic properties. J. Surg. Res., v.59, p.614-20, 1995

29 - HARAKAS, N.K. Demineralized bone-matrix-induced osteogenesis. Clin. Orthop., n.188, p.239-51, 1984.

30 - HOMMINGA, G.N.; BULSTRA, S.K.; KUIJER, R.; VAN DER LINDEN, A.J. Repair of sheep articular cartilage defects with a rabbit costal perichondrial graft. Acta Orthop. Scand., v.62, p.415-8, 1991.

31 - HUGGINS, C.; WISEMAN, S.; REDDI, A.H. Transformation of fibroblasts by allogeneic and xenogeneic transplants of demineralized tooth and bone. J. Exp. Med., v.132, p.1250-8, 1970.

32 - HUGGINS, C.B.; URIST, M.R. Dentin matrix transformation: rapid induction of alkaline phosphatase and cartilage. Science, v.167, p.896-8, 1970.

33 - INSALL, J. The pridie debridement operation for osteoarthritis of the knee. Clin. Orthop., n.101, p.61-7, 1974

34 - INSALL, J.N. Intra-articular surgery for degenerative arthritis of the knee. A report of the work of the late K. H. Pridie. J. Bone J. Surg., v.49-B, p.211-28, 1967.

35 - ITAY, S.; ABRAMOVICI, A.; NEVO, Z. Use of cultured embryonal chick epiphyseal chondrocytes as grafts for defects in chick articular cartilage. Clin. Orthop., n.220, p.284-303, 1987

36 - KAKIUCHI, M.; ONO, K.; NISHIMURA, A.; SHIOKAWA, H. Preparation of bank bone using defatting, freeze-drying and sterelisation with ethylene oxide gas. Int Orthop., v.20, p.142-6, 1996

37 - KILLIAN, J.T.; WILKINSON, L.; WHITE, S.; BRASSARD, M. Treatment of unicameral bone cyst with demineralized bone matrix. J. Pediatr. Orthop., v.18, p.621-4, 1998

38 - KIM, H.K.W.; MORAN. M.E., SALTER, R.B. The potential for regeneration of articular cartilage in defects created by chondral shaving and subchondral abrasion. An experimental investigation in rabbits. J. Bone Joint Surg., v.73-A, p.1301-15, 1991

39 - KUBLER, N.; REUTHER, J.; KIRCHNER, T.; PRIESSNITZ, B.; SEBALD, W. Osteoinductive, morphologic, and biomechanical properties of antigen-extracted allogeneic human bone. J. Oral Maxillofac. Surg., v.51, p.1346-57, 1993.

40 - LIETMAN, S.A.; YANAGISHITA, M.; SAMPATH, T.K.; REDDI, A.H. Stimulation of proteoglycan synthesis in explants of porcine articular cartilage by recombinant osteogenic protein-1 (bone morphogenetic protein-7). J. Bone Joint Surg., v.79-A p.1132-37, 1997.

41 - MANKIN, H. J. The Response of Articular Cartilage to Mechanical Injury. J. Bone Joint Surg., v.64-A, p.460-6, 1982.

42 - MICHELSON, J.D.; CURL, L.A. Use of demineralized bone matrix in hindfoot arthrodesis. Clin. Orthop., n.325, p.203-8, 1996

43 - MITCHELL, N.; SHEPARD, N. The resurfacing of adult rabbit articular cartilage by multiple perforations through the subchondral bone. J. Bone Joint Surg., v.58-A, p.230-3, 1976

44 - MOORE, T.M.; ARTAL, R.; ARENAS, M.; GENDLER, E. Influence of postmortem time and temperature on inductive activity of demineralized microperforated ethylene oxide-sterilized syngeneic bone implant in the rat. Clin. Orthop., n.259, p.239-44, 1990.

45 - MORAES, J.R.E.; MORAES, F.R. Effect of a persistent inflammatory process on experimental heterotopic ossification. The influence of macrophages. Brazilian J. Med. Biol. Res., v.26, p.53-66, 1993 
46 - MORAN, M.E.; KIM, H.K.W.; SALTER, R.B. Biological resurfacing of full-thickness defects in patellar articular cartilage of the rabbit. Investigation of autogenous periosteal grafts subjected to continuous passive motion. J. Bone Joint Surg., v.74 B, p.659-67, 1992

47 - MULLIKEN, J.B.; GLOWACKI, J. Induced osteogenesis for repair and construction in the craniofacial region. Plast. Reconstr. Surg., v.65, p.553-9, 1980.

48 - NATHANSON, M.A. Bone matrix-directed chondrogenesis of muscle in vitro. Clin. Orthop., n.200, p.142-57, 1985.

49 - NATHANSON, M.A. In vitro proteoglycan synthesis in response to extracts of demineralized bone. Clin. Orthop., n.299, p.263-81, 1994

50 - NATHANSON, M.A.; HILFER, S.R.; SEARLS, R.L. Formation of cartilage by nonchondrogenic cell types. Dev. Biol., v.64, p.99-117, 1978.

51 - NEIGEL, J.M.; RUZICKA, P.O. Use of demineralized bone implants in orbital and craniofacial reconstruction and a review of the literature. Ophtal. Plast. Reconstr. Surg., v.12, p.108-20, 1996

52 - NEWMAN, A.P. Articular cartilage repair. Am. J. Sports Med., v.26, p.309-24, 1998

53 - NOGAMI, H.; URIST, M.R. Explants, transplants and implants of a cartilage and bone morphogenetic matrix. Clin. Orthop., n.103, p.235-51, 1974.

54 - NOGUCHI, T.; OKA, M.; FUJINO, M.; NEO, M.; YAMAMURO, T. Repair of osteochondral defects with grafts of cultured chondrocytes. Comparison of allografts and isografts. Clin. Orthop., n.302, p.251-8, 1994

55 - O'DRISCOLL, S.W.; KEELEY, F.W.; SALTER, R.B. Durability of regenerated articular cartilage produced by free autogenous periostal grafts in major full-thickness in joint surfaces under the influence of continuous passive motion. A follow-up report at one year. J. Bone Joint Surg., v.70-A, p.595-606, 1988.

56 - O'DRISCOLL, S.W.; RECKLIES, A.D.; POOLE, A.R. Chondrogenesis in periosteal explants. An organ culture model for in vitro study. J. Bone Joint Surg., v.76-A, p.1042-51, 1994

57 - O'DRISCOLL, S.W.; SALTER, R.B. The repair of major osteochondral defects in joint surfaces by neochondrogenesis with autogenous osteoperiosteal grafts stimulated by continuous passive motion. Clin. Orthop., n.208, p.131-40, 1986.

58 - OIKARINEN, J. Experimental spinal fusion with decalcified bone matrix and deepfrozen allogeneic bone in rabbits. Clin. Orthop., n.162, p.210-8, 1982.

59 - RABIE, A.B.M. Vascular endothelial growth pattern during demineralized bone matrix induced osteogenesis. Connect. Tissue Res., v.36, p.337-45, 1997.

60 - RAY, R.D.; HOLLOWAY, J.A. Bone implants. Preliminary report of an experimental study. J. Bone Joint Surg., v.39-A, p.1119-28, 1957.

61 - REDDI, A.H.; HUGGINS, C. Biochemical sequences in the transformation of normal fibroblasts in adolescent rats. Proc. Natl. Acad. Sci. U.S.A., v.69, p.1601-5, 1972

62 - REDDI, A.H.; HUGGINS, C.B. Cyclic electrochemical inactivation and restoration of competence of bone matrix to transfom fibroblasts. Proc. Natl. Acad. Sci. U.S.A. v.71, p.1648-52, 1974.

63 - REDDI, A.H.; HUGGINS, C.B. Influence of geometry of transplanted tooth and bone on transplantation of fibroblasts. Proc. Soc. Exp. Biol. Med., v.143, p.634-7, 1973.

64 - RUBAK, J.M. Reconstruction of articular cartilage defects with free periosteal graft. An experimental study. Acta Orthop. Scand., v.53, p.175-80, 1982.

65 - SAKATA, H.: TAKAGI, K. Effect of bone marrow mononuclear phagocytes on the bone matrix-induced bone formation in rats. Clin. Orthop., n.220, p.253-8, 1987

66 - SALAMA, R.; BURWELL, R.G.; DICKSON, I.R. Recombined grafts of bone and marrow. The beneficial effect upon osteogenesis of impregnating xenograft (heterograft) bone with autologous red marrow. J. Bone Joint Surg., v.55-B, p.40217, 1973.

67 - SAMPATH, T.K.; NATHANSON, M.A.; REDDI, A.H. In vitro transformation of mesenchymal cells derived from embryonic muscle into cartilage in response to extracellular matrix components of bone. Proc. Natl. Acad. Sci. U.S.A., v.81, p.3419-23, 1984

68 - SAMPATH, T.K.; REDDI, A.H. Homology of bone-inductive proteins from human, monkey, bovine, and rat extracellular matrix. Proc. Natl. Acad. Sci. USA., v.80, p.6591-5, 1983.

69 - SATO, K.; URIST, M.R. Bone morphogenetic protein-induced cartilage development in tissue culture. Clin. Orthop., n.183, p.180-7, 1984

70 - SELLERS, R.S.; PELUSO, D.; MORRIS, E.A. The effect of recombinant human bone morphogenetic protein-2 (rhBMP-2) of the healing of full-tickness defects of articular cartilage. J. Bone Joint Surg., v.79-A, p.1452-63, 1997.

71 - SENN, N. On the healing of aseptic bone cavities by implantation of antiseptic decalcified bone. Am. J. Med. Sci., v.98, p.219-43, 1889

72 - SEYEDIN, S.M.; THOMAS, T.C.; THOMPSON, A.Y.; ROSEN, D.M.; PIEZ, K.A Purification and characterization of two cartilage-inducing factors from bovine demineralized bone. Proc. Natl. Acad. Sci. U.S.A., v.82, p.2267-71, 1985.

73 - SHARRARD, W.J.W.; COLLINS, D.H. The fate of human decalcified bone grafts. Proc. R. Soc. Med., v.54, p.1101-2, 1961.
74 - STEVENSON, S.; DANNUCCI, G.A.; SHARKEY, N.A.; POOL, R.R. The fate of articular cartilage after transplantation of fresh and cryopreserved tissue-antigenmatched and mismatched osteochondral allografts in dogs. J. Bone Joint Surg. v.71-A, p.1297-307, 1989

75 - SYFTESTAD, G.T.; CAPLAN, A.I. A fraction from extracts of demineralized adult bone stimulates the conversion of mesenchymal cells into chondrocytes. Dev. Biol., v.104, p.348-56, 1984.

76 - THIELEMANN, F.W.; SCHIMIDT, K.; KOSLOWSKI, L. Osteoinduction. Part II: Purification of the osteoinductive activities of bone matrix. Arch. Orthop. Traumat. Surg., v.100, p.73-8, 1982

77- UPTON, J.; BOYAJIAN, M.; MULLIKEN, J.B.; GLOWACKI, J. The use of demineralized xenogeneic bone implants to correct phalangeal defects: A case report. J. Hand Surg., v.9-A, p.388-91, 1984.

78 - URIST, M.R. Bone: formation by autoinduction. Science, v.150, p.893-9, 1965

79 - URIST, M.R.; DAWSON, E. Intertransverse process fusion with the aid of chemosterilized autolyzed antigen-extracted allogeneic (AAA) bone. Clin. Orthop., n.154, p.97-113, 1981

80 - URIST, M.R.; DOWELL, T.A.; HAY, P.H.; STRATES, B.S. Inductive substrates for bone formation. Clin. Orthop., n.59, p.59-95, 1968.

81 - URIST, M R : JURIST, J.M : DUBUC, F.L.; STRATES, B.S. Quantitation of new bone formation in intramuscular implants of bone matrix in rabbits. Clin. Orthop., n.68, p.279-93, 1970.

82 - URIST, M.R.; MIKULSKI, A.; LIETZE, A. Solubilized and insolubilized bone morphogenetic protein. Proc. Natl. Acad. Sci. USA., v.76, p.1828-32, 1979.

83 - URIST, M.R.; MIKULSKI, A.J. A soluble bone morphogenetic protein extracted from bone matrix with a mixed aqueous and nonaqueous solvent. Proc. Soc. Exp. Biol. Med., v.162, p.48-53, 1979

84 - URIST, M.R.; NOGAMI, H. Morphogenetic substratum for differentiation of cartilage in tissue culture. Nature, v.225, p.1051-2, 1970

85 - URIST, M.R.; SILVERMAN, B.F.; BÜRING, K.; DUBUC, F.L.; ROSENBERG, J.M. The bone induction principle. Clin. Orthop., n.53, p.243-83, 1967.

86 - URIST, M.R.; STRATES, B.S. Bone formation in implants of partially and wholly demineralized bone matrix. Including observations on acetone-fixed intra and extracellular proteins. Clin. Orthop., n.71, p.271-78, 1970.

87 - URIST, M.R.; WALLACE, T.H.; ADAMS, T. The function of fibrocartilaginous fracture callus. Observations on transplants labelled with tritiated thymidine. J. Bone Joint Surg., v.47-B, p.304-18, 1965

88 - VAN DE PUTTE, K.A.; URIST, M.R. Osteogenesis in the interior of intramuscula implants of decalcified bone matrix. Clin. Orthop., n.43, p.257-70, 1965

89 - WAKITANI, S.; GOTO, T.; PINEDA, S.J.; YOUNG, R.G.; MANSOUR, J.M.; CAPLAN A.I.; GOLDBERG, V.M. Mesenchymal cell-based repair of large, full-thickness defects of articular cartilage. J. Bone Joint Surg., v.76-A, p.579-92, 1994.

90 - WAKITANI, S.; KIMURA, T.; HIROOKA, A.; OCHI, T.; YONEDA, M.; YASUI, N.; OWAKI, H.; ONO, K. Repair of rabbit articular surfaces with allograft chondrocytes embedded in collagen gel. J. Bone Joint Surg., v.71-B, p.74-80, 1989

91 - WANG, E A : ROSEN, V: CORDES, P. HEWICK, R.M : KRIZ, M.J. LUXENBERG, D.P.; SIBLEY, B.S.; WOZNEY, J.M. Purification and characterization of other distinct bone-inducing factors. Proc. Natl. Acad. Sci. U.S.A., v.85, p.9484-8, 1988.

92 - WANG, EA : ROSEN, V: D'ALESSANDRO, J.S.; BAUDUY, M.; CORDES, P. HARADA, T.; ISRAEL, D.I.; HEWICK, R.M.; KERNS, K.M.; LAPAN, P.; LUXENBERG, D.P.; MCQUAID, D.; MOUTSATSOS, I.K.; NOVE, J.; WOZNEY, J.M. Recombinant human bone morphogenetic protein induces bone formation. Proc. Natl. Acad. Sci. USA., v.87, p.2220-4, 1990

93 - WITTBJER, J.; PALMER, B.; THORNGREN, K.-G. Osteogenetic properties of reimplanted decalcified and undecalcified autologous bone in the rabbit radius. Scand. J. Plast. Reconstr. Surg., v.16, p.239-44, 1982.

94 - WOZNEY, J.M.; ROSEN, V.; CELESTE, A.J.; MITSOCK, L.M.; WHITTERS, M.J.; KRIS, R.W.; HEWICK, R.M.; WANG, E.A. Novel regulators of bone formation: molecular clones and activities. Science, v.242, p.1528-34, 1988.

95 - YAMASHITA, F.; SAKAKIDA, K.; SUZU, F.; TAKAI, S. The transplantation of an autogeneic osteochondral fragment for osteochondritis dissecants of the knee. Clin. Orthop., n.201, p.43-50, 1985

96 - YEOMANS, J.D.; URIST, M.R. Bone induction by decalcified dentine implanted into oral, osseous and muscle tissues. Arch. Oral Biol., v.12, p.999-1008, 1967.

97 - ZHANG, Q.; CORNU, O.; DELLOYE, C. Ethylene oxide does not extinguish the osteoinductive capacity of demineralized bone. A reappraisal in rats. Acta Orthop. Scand., v.68, p.104-8, 1997. 